\title{
Aktarım Mekanizmasının Hisse Senedi Fiyatları Kanalının Etkinliğine ilişkin Bir Analiz ${ }^{*}$
}

\author{
Durmuş Çağrı YILDIRIM, Mustafa Uğur MiRASEDOĞLU**
}

\begin{abstract}
Aktarım Mekanizmasının Hisse Senedi Fiyatları Kanalının Etkinliğine İlişkin Bir Analiz

Özet

Finansal kriz sonrasında para politikası uygulamalarının etkinliği makroekonomik istikrarın sağlanmasının yanı sıra krizlerle mücadelede daha önemli bir konu haline gelmiştir. Parasal aktarım mekanizması merkez bankalarının para politikası uygulamaları dolayısıyla hasıla ve enflasyonu etkileme sürecini ifade etmektedir. Parasal aktarım mekanizması içerisinde birçok kanal bulunmakla birlikte bizim çalışmamızın konusunu hisse senedi fiyatları kanalı oluşturmaktadır. Bu çalışmada Merkez Bankasının örtük enflasyon hedeflemesine geçmiş olduğu 2002 ylından 2014 yılının ikinci çeyreğine kadar geçen sürede Türkiye'de parasal aktarım mekanizmasının hisse senedi fiyatları kanalının etkinliği araştııımıştır. Çalışmanın sonucunda ilgili dönemde hisse senedi fiyatları kanalının etkin bir şekilde çalışmadığı sonucuna ulaşımıştır.
\end{abstract}

Anahtar Kelimeler: Parasal Aktarım Mekanizması, Varlık Fiyatları Kanalı, Hisse Senedi Fiyatları Kanalı, VAR Analizi, Etki-Tepki Analizi.

\section{Giriş}

Politika yapıcılar, hane halkı ve firmaların kararlarına ve fiyatlar genel seviyesine doğrudan etki edememektedirler. Dolayısıyla da fiyatlar genel seviyesini doğrudan kontrol edememektedirler. Bu nedenle politika yapıcıların, öncelikle çıktı ve fiyatlar genel seviyesini kontrol edebilecek olan değişkenleri tespit etmeleri gerekmektedir. Tespit edilen bu değişkenlerin fiyatlar genel seviyesini hangi

\footnotetext{
* Bu makale BEYKON 2014'de sunulmuş ve bildiri kitabında yayınlanmış olan “Türkiye'de Hisse Senedi Fiyatları Kanalının Etkinliğine İlişkin Bir Analiz" adlı çalışmamızın genişletilmiş halidir.

*** Durmuş Çağrı YILDIRIM, Doç.Dr., Namık Kemal Üniversitesi, İktisat Bölümü, cyildirim81@gmail.com; Mustafa Uğur MiRASEDOĞLU, Arş.Gör., Recep Tayyip Erdoğan Üniversitesi, Bankacılık ve Finans Bölümü, ugurmirasedoglu@gmail.com
} 


\section{Durmuş Çağrı YILDIRIM | Mustafa Uğur MiRASEDOĞLU}

aktarım kanalları yolu ile etkileyeceklerinin iyi incelenmesi ve merkez bankalarının uygulayacakları para politikalarını bu tespitlerine göre gerçekleştirmeleri gerekmektedir (Önder, 2005).

2008 finansal krizi, para politikası uygulamalarının etkinliğinin sorgulanmasına neden olmuştur. Küresel finansal krizle birlikte hem gelişmiş hem de gelişmekte olan ülke merkez bankalarının fiyat istikrarı yanında önemli bir diğer hedefi finansal istikrar haline gelmiştir. Ancak para politikası uygulamalarının etkinliği makroekonomik istikrarın sağlanmasının yanı sıra krizlerle mücadelede merkez bankaları için önemli de bir konu haline gelmiştir.

Para politikası belirleyicileri tarafından uygulanan politikaların ve alınan kararların ekonomi üzerinde ne tür etkilerinin olacağı, gerek ekonomistler ve gerekse de para politikası belirleyicilerinin kendileri tarafından anlaşımaya çalışımıştır. Bu konu özellikle son yıllarda pek çok çalışmanın konusu olmuştur. Bu etkileşim sisteminin tam manasıyla belirlenerek formüle edilebilmesinin mümkün olmaması nedeniyle, bazı ekonomistler tarafından parasal aktarım mekanizması "kara kutu" olarak adlandırımıştır. Uygulanan para politikasının ekonomiye olan etkisinin daha iyi tahmin edilebilmesi ve politikalar aracılığıyla ulaşılmak istenen hedeflerin politika belirleyicileri tarafından daha doğru seçilebilmesi ancak politika kararları ile ekonomi arasındaki etkileşimin hangi yollarla olduğunun ve farklı parasal aktarım mekanizması kanallarının ekonomi üzerinde nasıl bir etki gösterdiklerinin belirlenmesi ile mümkün olabilmektedir (Önder, 2005).

Para politikası etkili bir araç olarak değerlendirilmekle birlikte beklenmedik ya da istenmedik sonuçlara da neden olabilmektedir. Para politikasının uygulamalarında başarılı olabilmek, politika yapıcıların doğru zamanlama yapabilmelerine ve aktarım mekanizmasının hangi kanalının ekonomiyi ne derece etkilediğini anlayabilmelerine bağlıdır (Mishkin, 1995).

Parasal aktarım mekanizması, para politikası kararlarında meydana gelen değişikliklerin fiyat ve hasıla düzeyleri üzerindeki etki sürecidir. Burada para politikası kararlarındaki değişiklik ile ifade edilmek istenen politika faiz oranlarındaki ya da nominal para stokundaki değişikliklerdir. Parasal aktarım mekanizmasındaki kanallar yoluyla bu değişkenlerle fiyat düzeyi, hasıla düzeyi gibi değişkenler arasında bir etkileşim gerçekleşmektedir (Ireland, 2005).

Tarihsel süreç incelendiğinde parasal aktarım mekanizmalarına yönelik baskın 2 görüş yer almaktadır; Keynesyen Görüş ve Parasalcı Görüş.

> Keynesyen Görüş: Büyük Buhran ile beraber iktisadi düşüncede devletlerin uygulamakta oldukları mali politikaların para politikalarına kıyasla ekonomik faaliyetleri etkilemekte daha başarılı oldukları görüşü ağılık kazanmıştır. Keynes'in öncülüğünü yaptığı bu görüş genel olarak politika otoriteleri tarafından da kabul görmüş ve enflasyon, işsizlik gibi sorunların çözümünde 1970’lere kadar başarılı olmuştur. Keynesyen görüşte para politikası sadece faiz oranlarını etkileyebildiği sürece talep düzeyine bir etki sağlayabilmektedir (TCMB, 2013). 
Parasalcı Görüş: 1960'larda para politikasının ekonomiler üzerindeki etkisinin yalnızca faiz oranlarıyla yatıım harcamaları arasında bulunan ilişkiye dayandıılarak açıklanmasının yanış olduğunu savunan Friedman'ın öncülük ettiği “Parasalcılar”, faiz kanalı dışında birçok kanal üzerinden para politikasının toplam talep üzerinde etkisi olduğunu öne sürmüşlerdir. Keynesyen görüşteki iktisatçıların savunduklarının aksine, ekonomik kararlar alınırken reel faiz oranlarının belirleyici olduğunu savunmuşlardır (TCMB, 2013).

Çalışmamızın konusunu parasal aktarım mekanizmasının hisse senedi fiyatları kanalı oluşturmaktadır. Çalışmamııın birinci bölümünde parasal aktarım mekanizması kanalları tanıtılacaktır. İkinci bölümünde literatür araştırması yer almaktadır. Üçüncü bölümünde ekonometrik analiz yer almaktadır.

\section{Parasal Aktarım Mekanizması Kanalları}

Literatürde parasal aktarım mekanizması kanalları faiz kanalı, döviz kuru kanalı, varlık fiyatları kanalı ile kredi kanalı olarak yer almaktadır. Para politikasında meydana gelen bir değişme öncelikle faiz oranlarını, sonrasında varlık fiyatları ve döviz kurunu ve son olarak da beklentileri etkileyerek fiyat ve hasıla seviyesini etkilemektedir. Para politikasındaki uygulamaların fiyat ve hasıla düzeylerini hangi kanallar yardımıyla etkilemekte olduğunun tespiti kadar bu kanalların etkililik seviyelerinin de incelenmesi oldukça önemlidir. Çünkü kanalların etki gücünün belirlenmesi politika yapıcılara yol gösterecektir (Erdoğan ve Yıldırım, 2008).

\subsection{Geleneksel Faiz Kanalı}

Faiz kanalı parasal aktarım mekanizmaları içerisindeki geleneksel kanaldır. Faiz kanalının işleyiş şeklinde para politikasının belirleyicisi parasal borçlanmanın marjinal maliyetinde değişiklik yaparak hem tüketicilerin tüketim kararlarını ve nakit akışlarını hem de üreticilerin harcama kararları ile yatırım kararlarını etkilemektedir. Nihayetinde toplam talebi etkilemektedir. Faiz kanalının işleyişini bir örnek yardımı ile açıklarsak eğer, faiz oranlarındaki düşüş sermaye maliyetlerinde azalmaya neden olarak yatırım harcamalarında artışa neden olacaktır. Bu artış da toplam talepte canlanma sağlayarak üretimde artışa neden olacaktır. Diğer yandan faiz oranlarındaki düşüş sonucunda tüketicilerdeki tasarruf eğilimi azalacak ve tüketim harcamalarında artışa neden olacaktır (TCMB, 2013)

\subsection{Döviz Kuru Kanalı}

Parasal aktarım mekanizmalarından olan döviz kuru kanalı, para politikası kararlarında meydana gelen bir değişimin ulusal para biriminin değerini ve bunun sonucunda da net ihracat düzeyini etkileyerek fiyatlar genel düzeyini ve reel hasılayı değiştirme sürecini ifade etmektedir. Döviz kuru kanalının işleme şekli, ekonomilerin sahip oldukları dışa açıklık seviyesine bağlı bulunmaktadır. Global ekonomi ile bütünleşme sürecinin hızlanması, diğer bir ifade ile dışa açıklık seviyesinde meydana gelen artış, döviz kuru kanalını daha da önemli hale getirmiştir (Boughara, 2003).

Para politikası kanallarında meydana gelen bir değişiklik döviz kuru kanalıyla hem gelir seviyesini hem de fiyatlardaki değişiklikler nedeniyle ithalat seviyesini etkilemektedir. Kısa vadeli faiz oranlarının arttııılmasıyla ulusal para birimi değerlenmekte ve dolayısıyla döviz kuru düşmektedir. Artan faiz 


\section{Durmuş Çağrı YILDIRIM | Mustafa Uğur MiRASEDOĞLU}

oranları ulusal para cinsi varlıkların getirisinde artış sağlayacaktır. Bunun sonucu olarak yabancı sermaye girişinde artış sağlanacaktır. Ulusal para biriminin değerlenmesiyle ihracat azalırken ithalat artacaktır. Net ihracattaki azalış aynı zamanda toplam talep seviyesinde düşüş anlamına gelmektedir.

Ulusal para biriminin değerlenmesi sonucunda yabancı mal fiyatlarında meydana gelen göreli düşüş ekonomideki fiyatlar genel düzeyinde bir azalış da sağlayabilmektedir. Bu daha çok yurt içi tüketimindeki yerel mal ve ithal mal ağılıklarına bağlı olarak, ekonomilerde farklılık gösterebilecek bir sonuçtur. Diğer taraftan, üretiminde çoğunlukla ithal ara mallarını kullanan ekonomilerde ulusal para biriminin değer kazanması girdi maliyetlerinin düşmesine ve dolayısıyla üretim maliyetlerinde azalışa neden olabilmektedir. Sonuç olarak, parasal bir şok sonrasında döviz kurlarında meydana gelen değişikliklerin hem reel sonuçları hem de nominal sonuçları olabilmektedir (Erdoğan ve Yıldıım, 2008).

\subsection{Kredi Kanalı}

Finans piyasaları eksik rekabet koşulları altında çalışmaktadır. Finans piyasalarında büyük miktarlarda bilgi akışı ve dolayısıyla işlem maliyetleri bulunmaktadır. Bu gerçekliğin doğal bir sonucu olarak da, piyasa aktörlerinin tam bilgiye sahip oldukları varsayımı 1970'lere gelindiğinde ciddi eleştiriler almış ve piyasada tam bilginin olamayacağı varsayımı kabul edilmiştir. Eksik bilgi modeli literatüre Akerlof'un limon araba modeli ile girmiştir. Bu modelde Akerlof, alııılar ve satıcılar arasında bulunan asimetrik bilginin piyasa dengesinin sağlanmasını ne şekilde engellediğini göstermektedir (Gür, 2003).

Akerlof'un limon araba modeli kalitenin belirsizliği esasına yani asimetrik bilgi akışına dayanmaktadır. Bu modelde satışa sunulan ikinci el arabaların kalitelerini arabaları satanların bildikleri fakat alıcıların arabaların kaliteleri hakkında kapsamlı bilgilerinin olmadıkları varsayılmaktadır. Böyle bir durumda alıcılar ödeyecekleri fiyatı ortalama bir arabanın kalite düzeyine göre tahmin yaparak belirlemek zorundadırlar. Bu fiyattan satış yapmaya razı olan satıılar ise, arabaları iyi kalitede olan satıcıları piyasanın dışına itecek şekilde sadece kötü kalitedeki arabaların satıcıları yani limon araba satıcıları olacaktır. Bu da kaliteli mal satııları ile kalitesiz mal satıcıları arasında bulunan dışsallıktan kaynaklı bir piyasa başarısızlığıdır (Akerlof, 1970).

Finans piyasalarında gerçekleşen işlemlerde en doğru kararı vermek isteyen taraflar birbirleri hakkında tam bilgiye sahip değillerdir. Birbirleri hakkındaki bilmek istedikleri her şeyi bilememektedirler. Finans piyasalarındaki önemli bir özellik olan bu asimetrik bilgi akışı sorunu, taraflar arasında bulunan bu eksik bilgiden kaynaklanmaktadır ve diğer piyasalara benzer şekilde kredi piyasasında da asimetrik bilgi akışı sorunundan kaynaklanan iki ana sorun vardır. Bunlardan ilki ters seçim sorunu ve diğeri ise ahlaki tehlike sorunudur (Ökte, 2001).

Ters seçim sorunu kredi sözleşmesi yapılmadan önce gerçekleşmektedir. Bu sorun, krediyi verenlerin kredi almak isteyenler hakkında tam bilgiye sahip olamamalarından, kredi almak isteyenler hakkında bilinmesi gereken tüm özellikleri bilememelerinden ortaya çıkmaktadır. Gerçekleştirilmek 
istenen projenin beklenen getirisi girişimci tarafından bilinmekte ancak banka bu getiri hakkında hiçbir bilgiye sahip olamamaktadır. Başka bir deyişle, bankalar kötü kredi ile iyi kredi risklerini birbirlerinden ayıramamaktadırlar. Ahlaki tehlike sorunu ise, bankaların krediyi verdikten sonra kredi alanların gerçekleştirdikleri faaliyetleri gözleyememesinden kaynaklanmaktadır. Bu sorunun temel sebebi ise kredi alanların bu kredileri getirisi yüksek ama aynı zamanda riski de yüksek olan projelerde kullanmak isteme eğiliminde olabilmeleridir (Mishkin, 1997).

Kredi piyasalarında yaşanan asimetrik bilgi sorunu sıkı para politikası uygulanan dönemlerde daha da önemli hale gelmektedir. Bunun sonucunda iç ve dış finansman fonları arasında fark yani dış finansman priminde artış gerçekleşmektedir. Bu dış finansman priminin büyüklüğü, potansiyel borçlu durumda olanların maliyetleri ile bankaların beklenen getirileri arasında bulunan farkı yönlendiren kredi piyasalarındaki eksikliği yansıtmaktadır. Para politikasında faiz oranlarını değiştiren bir operasyon, dış finansman primini de aynı yönde değiştirmektedir. Böylece kredi kanalında, para politikasının dış finansman primi üzerinde sahip olduğu etki nedeniyle, reel faaliyetlere son etkisi daha da artmaktadır (Bernanke ve Gertler, 1995).

Kredi kanalında, para politikası ile dış finansman primi arasındaki ilişkiyi açıklamaya yönelik iki kanal mevcuttur. Bunlardan birincisi bilanço kanalıdır ve ikincisi de banka kredi kanalıdır. Bilanço kanalı, para politikasında olası bir değişikliğin borçlu tarafın likit varlıkları, nakit akışı ve net değeri gibi değişkenleri de içermekte olan gelir tablosu ve bilançosu üzerindeki etki potansiyelini vurgulamaktadır. Banka kredi kanalı ise, kredi veren kuruluş tarafından sağlanacak olan kredi üzerinde para politikasının etkisini daha dar bir çerçeveden incelemektedir (Bernanke ve Gertler, 1995). Bunlara ek olarak, "hanehalkı bilanço etkileri", "beklenmeyen fiyat düzeyi kanalı" ve "nakit akışı kanalı"'da bilanço kanalı içerisinde değerlendirilmektedir (Mishkin, 1996).

\subsection{Varlık Fiyatları Kanalı}

Varlık fiyatları kanalında farklı türden varlıkların nispi fiyatlarının ekonomik faaliyetlere etkisi incelenmektedir. Para politikasındaki değişiklikler sonucunda reel varlıkların ve finansal varlıkların nispi fiyatlarında değişimler gerçekleşmesi sonucunda toplam talep ve üretimde değişmeler meydana gelmektedir (Kosfeld, 2002).

Para politikasındaki değişiklikler gayrimenkul, hisse senedi ve bono gibi varlıkların fiyatlarını etkilemektedir. Varlık fiyatlarında meydana gelen bir düşüş hanehalkları ve firmaların borçlarını ödemekte zorlanmalarına neden olabilmekte ya da borçlarını ödemelerinin zorlaşacağını düşünmelerine neden olabilmektedir. Bunun sonucunda borçlanma ve harcamalarını azaltmaya giderek bilançolarını güçlendirmeye yönelik bir pozisyon seçebilirler (Kasapoğlu, 2007).

Merkez bankalarınca uygulanan para politikalarının toplam talep üzerine etkileri, varlık fiyatlarındaki değişmelere ve bilançolarda oluşan değişmelere iktisadi birimlerin tepki vermesiyle daha da güçlenebilmektedir. Örnek olarak faiz oranlarında bir artış durumu ele alınırsa, bu durum sonucunda varlık fiyatları düşmekte ve bilanço pozisyonları zayıflamaktadır. Başlangıçta bu durum toplam üretim seviyesinde ve dolayısıyla toplam gelirde bir azalışa neden olmaktadır. Ekonomik faaliyetlerde meydana gelen bu durum sonucunda hanehalklarının ve firmaların nakit akışları zayıflamakta ve bu 


\section{Durmuş Çağrı YILDIRIM | Mustafa Uğur MiRASEDOĞLU}

da onların finansal sıkıntıları karşısında daha da savunmasız hale gelmelerine neden olmaktadır. Bu durum onların toplam tüketimlerinde ikincil bir azalma gerçekleşmesine sebep olmaktadır (Kamin ve diğerleri, 1998).

Varlık fiyatları kanallarından biri olan hisse senedi fiyatları kanalında kabul gören önemli teorilerden biri Tobin'in q teorisidir. Bu teoride Tobin, hisse senedi fiyatlarında meydana gelen değişiklikler sonucunda, firmaların piyasa değerlerinin değişeceğini ve bu değişikliğe bağlı olarak da firmaların yatırım düzeylerini değiştirebileceklerini söylemektedir. Tobin'in teorisinde bulunan q'nun değeri hisse senedi fiyatları yoluyla belirlenen firmanın piyasa değerinin, firmanın sahip olduğu fiziki sermayelerinin yenilenme maliyetlerine bölünmesi ile bulunmaktadır. Buradan elde edilen q değerinin yüksekliği, firmaların piyasa değerlerine kıyasla yeni teçhizat veya üretim merkezi elde etmelerinin maliyetlerinin çok daha düşük seviyede olduğunu göstermektedir. Böyle bir durumda firmaların yeni yatırımlar yapabilmeleri için az miktarda hisse senedini piyasaya sürmeleri yeterli olmaktadır. Böylece firmalar, yatırım harcamalarını artırmaktadır. Tam tersi durumda yani q'nun düşük olduğu durumda ise firmaların yatırım harcamalarını gerçekleştirebilmeleri için daha yüksek miktarlarda hisse senedini piyasaya sürmeleri gerekmektedir. Bu durumda ise firmalar yatırım harcamalarında azalmaya gitmektedirler. Hisse senedi kanalı firmaların yatırım kararlarını bu yollarla etkileyebilmektedir (Mishkin, 1996).

Hisse senedi fiyatları yoluyla işleyen bir başka kanal da tüketimde servet (refah) etkisidir. Servet etkisi Modigliani'nin yaşam boyu gelir hipotezine dayanmaktadır. Bu hipoteze göre tüketim harcamalarını; reel sermaye, finansal servet ve beşeri sermayenin oluşturduğu yaşam boyunca elde edilen kaynaklar belirlemektedir. Finansal servetlerin içerisinde ise hisse senetleri önemli yere sahiptir. Uygulanan para politikaları sonucunda hisse senetlerinin fiyatlarının değişmesi tüketim kararlarını da etkilemektedir. Bu etki; hisse senetleri fiyatlarında meydana gelen bir artış sonucunda finansal servet değerinde de artış meydana gelmesiyle gerçekleşmektedir. Bu sayede tüketicilerin yaşam boyu servetlerinde artış meydana gelmekte ve bunun sonucunda da tüketim harcamaları artmaktadır (Mishkin, 1996). Ancak buraya kadar bahsedilenler firmaların hisse senetlerini finansman aracı olarak tercih etmesine ya da en azından finansmanlarının bir kısmını hisse senedi üzerinden sağlamalarına bağlıdır. Firmaların finansman olanakları için mevcut 3 teori bulunmaktadır: Modigliani ve Miller teoremi, Dengeleme Kuramı ve Finansal Hiyerarşi Teoremi.

İşletmelerin sahip oldukları sermaye yapılarına yönelik temel taşı kabul edilebilecek ilk çalışma Modigliani ve Miller'in yaptığı ve literatüre M-M teoremi olarak geçen çalışmadır. Bu alanda 1958 yılında yaptıkları ilk çalışmalarında, piyasaların mükemmel işlediği durumlarda, başka bir ifadeyle, vergi, temsilci maliyetleri, iflas maliyetleri ve piyasa aksaklıklarının bulunmadığı durumlarda, sahip olunan sermaye yapılarının işletmelerin değerini etkilemediği, işletme değerinin borçlanma miktarının artırımasıyla değiştirilemeyeceğini öne sürmüşlerdir (Modigliani ve Miller, 1958). Fakat 5 yıl sonra 1963 yılında yayınladıkları ve ilk makalelerini düzelttikleri ikinci makalelerinde borçlanma so- 
nucu doğan faiz ödemelerinin vergi matrahını azaltmakta olduğunu ve daha az ödenen vergi sonrasında sermayenin maliyetini azalttığı için borçlanmanın, hisse senedi yoluyla öz sermaye kullanımından daha avantajlı olduğunu ileri sürmüşlerdir (Modigliani ve Miller, 1963).

1999 yılına gelindiğinde ise Brealey tarafından ortaya atılan Dengeleme Kuramı ön plana çıkmaktadır. İ̧letmelerin borçlanma ile öz sermaye kullanımı arasındaki seçimi bu kurama göre, borçlanma faizinin sağladığı vergi tasarrufu ile finansal sıkıntılardan doğan maliyetler arasında yer alan bir denge noktasında bulunmalıdır. Yani işletmelerin borçlanmaya çalışacakları bu denge noktası, borçlanma faizinin sağladığı vergi tasarrufu nedeniyle borçlanmanın faydası ile kredibilitedeki azalışlar nedeniyle borçlanmanın neden olduğu zarar arasındaki farkın en çok olduğu noktadır. Bu amaç temelinde işletmeler, sahip oldukları koşullar doğrultusunda kendilerine bir hedef borçlanma oranı belirlerler ve bu oranı hedefleyerek borçlanmalarını gerçekleştirirler. Dengeleme Kuramı ise, hedeflenen borç oranlarının işletmeler arasında farklııılar gösterebileceğini kabul etmektedir. Mali açıdan güvenilir durumda olan, maddi duran varlıklara sahip olan ve vergilendirilebilen karları tasarruflarına kıyasla yeterli ölçüde yüksek olan işletmelerin hedefledikleri borçlanma oranları da yüksek olmalıdır. Riskleri bulunan, sahip olduğu varlıkları maddi olmayan ve karları bulunmayan işletmeler ise finansmanlarını öz kaynaklarına dayandırmalılardır. Kurumlar vergisi ödeyen tüm işletmelerin borçlanmalarını olabildiğince çok gerçekleştirmelerini öneren Modigliani ve Miller kuramının aksine dengeleme kuramı önceden belirlenmiş bir denge noktasında ve ılımlı bir borçlanma oranı önermektedir (Okuyan ve Taşç, 2009)

Sermaye yapısına yönelik teoriler literatüründe Myers ve Majluf tarafından ortaya atılmış olan Finansman Hiyerarşisi Teorisi en etkili olan teorilerden biridir. Finansman hiyerarşisi teorisine göre işletmeler faaliyetlerinin finansmanını sağlarken, öncelikle kendi iç kaynaklarından yani dağııılmamış karlarından ve sermaye yedeklerinden faydalanmalıdırlar. Bunların yetersiz olduğu durumlarda eğer ki dış kaynak kullanmaları gerekirse öncelikle yabancı kaynak kullanımını tercih etmelidirler. Yabancı kaynak kullanımının da yetersiz kaldığı durumlarda ise hisse senedi ihraç edilmesi yolu en son tercih ettikleri yol olmalıdır. Hisse senedi ihracı yolu ile finansman sağlanması finansman hiyerarşisi teorisine göre nadiren kullanılan bir finansman sağlama yolu olarak karşımıza çıkmaktadır (Sayman, 2012).

Varlık fiyatları kanallarından bir diğeri olan konut fiyatları kanalında ise ekonomi para politikasındaki değişiklikler sonucunda konut fiyatlarında gerçekleşen değişmeler ile iki farklı şekilde etkilenmektedir. Burada yine servet etkisi ve Tobin q teorisi geçerli kabul görülmektedir. Servet etkisi bağlamında incelendiğinde, uygulanan para politikaları sonucunda konut fiyatlarında gerçekleşen artışlar konut sahiplerinde refah artışı sağlamaktadır. Konut sahiplerinin refah seviyelerinde gerçekleşen bu artışlar sonrasında, toplam hasıla ve toplam talep seviyeleri tüketim harcamalarındaki artışlar sebebiyle etkilenmektedir. Konut fiyatlarındaki değişmelerin ekonomiye diğer bir etkisi ise Tobin q teorisi ile açıklanmaktadır. Bu teori çerçevesinden incelendiğinde yerine koyma maliyetlerindeki değişmelere kıyasla konut fiyatlarında gerçekleşen değişmelerin, yatırım harcamalarını etkilemek suretiyle toplam talep ve toplam hasıla seviyelerini etkilediği görülmektedir.(Mishkin, 1996) 


\section{Durmuş Çağrı YILDIRIM | Mustafa Uğur MiRASEDOĞLU}

\section{Literatür Araştırması}

Literatürde parasal aktarım mekanizmasının hisse senedi fiyatları kanalına ilişkin olarak birçok çalışma yer almaktadır. Bu çalışmalardan bazılarına aşağıda yer verilmiştir.

Kearney (1996), yaptığı ampirik çalışmada bağımlı değişken olarak 1977-1984 yıl aralığında S\&P 500 fiyat endeksini seçmiştir ve bu endeksin beklenmedik M1 ve M2 para arzı ile etkileşimini incelemiştir. Çalışmasında beklenmedik M1 ve M2 para arzı değerlerine her iki değer için de beklentilerle gerçekleşen değerlerin logaritmaları arasındaki farkı alarak ulaşmıştır. Kearney yaptığı bu çalışmada hisse senedi fiyatlarının beklenmedik para arzı değişikliklerinden olumsuz etkilendiğini ve bu etkinin şiddetinin FED'in izlediği o anki politika prosedürüne bağlı olduğunu göstermiştir. Ayrıca Kearney çaIışmasında, FED'in önceliklerinin piyasa aktörleri tarafından iyi bilinmesi halinde, hisse senedi fiyatlarının tepki kaynaklarında da değişmeler olduğunu söylemiştir. Buna örnek olarak FED'in öncelikli politika olarak istihdam arttırıcı bir politika benimsemesi ve piyasa aktörleri tarafından bunun bilinmesi halinde, hisse senedi fiyatlarının tepkisinin beklenmedik para arzı değişikliklerinden çok beklenenin dışında gerçekleşen istihdam raporlarına yönelik olacağını belirtmiştir. Buradan yola çıkarak para politikasının hisse senedi fiyatları üzerine etkisinin FED'in önceliklerine göre değişiklik gösterdiğini belirtmiştir.

Lastrapes (1998) ve Rapach (2001), her iki yazar da çalışmalarında uzun dönem kısıtlarını kullanmışlardır ve bu kısıtlarla kurdukları VAR modellerinde parasal şokların hisse senedi fiyatları üzerine etkilerini analiz etmişlerdir. Lastrapes savaş sonrası dönemde G-7 ülkeleri ve Hollanda olmak üzere sekiz sanayileşmişülkeye ait uzun dönem devlet tahvilleri, sanayi üretimi, hisse senetleri fiyatları endeksi, M1 para arzı ve nominal değerleri enflasyondan arındırabilmek için tüketici fiyat endeksi verilerini kullanmıştır. Ülkeler arasında farklııklar olmakla birlikte genellikle tüm ülkelerde 19601994 arası dönemleri incelemiştir. Rapach ise 1995'in ilk çeyreğinden 1999'un ilk çeyreğine kadar ki dönemde para arzı, tahvil, toplam harcama ve toplam arz şoklarının fiyat düzeyi, reel hisse senedi fiyatları, faiz oranı ve reel çıktı üzerine etkisini incelemiştir. Her ikisi de yaptıkları çalışmalar sonucunda parasal şokların hisse senedi piyasaları üzerinde güçlü etkilerinin olduğu sonucuna varmışlardir.

Rigobon ve Sack (2004), the Dow Jones Industrial Avarage, the S\&P 500, the Nasdaq ve the Wilshire 5000 endekslerini kullanarak hisse senedi piyasası üzerinde para politikasının sahip olduğu etkiyi analiz edebilmek amacıyla yaptıkları çalışmada, beklenmedik bir faiz artışı şokunu izleyerek hisse senedi fiyatlarında büyük ölçüde azalış gerçekleştiğini görmüşlerdir. Parasal şokların hisse senedi fiyatlarını güçlü şekilde etkilediği sonucuna ulaşmışlardır.

Conover, Jensen ve Johnson (1999), sanayileşmiş 16 ülke ile ilgili yaptıkları bir çalışmada, yabancı ülkelerdeki hisse senetleri getirilerinin hem ABD'nin gerçekleştirdiği para politikası uygulamalarına hem de o ülkelerin kendi gerçekleştirdikleri para politikası uygulamalarına tepki verdiklerini tespit etmişlerdir. 
Neri (2002), G-7 ülkeleri ve İspanya'nın verilerini kullanarak hazırladığı ampirik çalışmada elde ettiği bulgulara göre Fransa hariç tüm diğer ülkelerde parasal şokların hisse senedi fiyatları üzerinde anlamlı etkisi olduğunu tespit etmiştir. Bu çalışmada gerçekleştirilen VAR analizi sonuçlarına göre tüm bu ülkelerde parasal şokun hisse senedi fiyatları üzerine etkileri olmakla beraber bu etkiler değişiklik göstermektedir. Etkilerdeki oynaklık dışında etkilerin genellikle kısa dönemli olduğu da tespit edilmiştir.

Bernanke (2003), yaptığı çalışmada esnek para politikası uygulamalarının sadece hisse senedi fiyatlarında artış sağlamakla kalmayıp, aynı zamanda risk primlerini de düşürdüklerini belirtmiştir. Risk primlerinde gerçekleşen bu düşüş diğer bir yandan da finansal ve ekonomik dalgalanmaların azalması anlamına gelmesi nedeniyle finansal yatırımcılarda risk alma kapasitelerini artırmaktadır. Bu nedenle esnek para politikası uygulamaları yatırımcıların portföylerinde bulunan hisse senedi varIıklarından cari dönemde sermaye getirisi elde etmelerini sağlamakla kalmayıp aynı zamanda finansal ve ekonomik risk algılarını da düşürmektedir. Yatııımcıların risk algılarında gerçekleşen bu azalma ise tasarruflarda azalmaya neden olmaktadır. Buradan da esnek para politikası uygulamalarının yalnızca hisse senedi fiyatlarında yükselişe neden olmakla kalmayıp aynı zamanda yatıımcılardaki risk algısında azalışa neden olması nedeniyle önem taşıdığı anlaşılmaktadır.

Kulhánek (2012), OECD ülkelerinin verilerini kullanarak yaptığı ampirik çalışmada uzun dönemde hisse senedi fiyatları kanalının analize dahil edilen tüm ülkelerde ekonomik aktivitede etkin rolü olduğunu tespit etmişlerdir. Ancak kısa dönemde bu etki ülkeler arasında çok büyük farklılıklar göstermektedir.

Literatürde Türkiye'de hisse senedi fiyatları kanalının çalışmasının araştırımasına yönelik çok sayıda önemli ampirik çalışma da bulunmaktadır. Bu çalışmalarda ağırlıklı görüş Türkiye'de hisse senedi fiyatları kanalının etkin bir şekilde çalışmadığı görüşüdür.

Örnek (2009), geleneksel modele IMKB endeksini ekleyerek yapmış olduğu etki tepki analizinin sonuçları incelendiğinde Türkiye'de hisse senedi endekslerinin faiz oranındaki şoklara karşı duyarsız oldukları görülmektedir. Buradan IMKB endeksi üzerinde para politikasının etkin bir rolünün olmadığı anlaşılmaktadır. Aynı çalışmada IMKB endeksindeki bir standart sapmalık şokun reel üretimde anlamlı bir tepki ile karşılık bulmadığı belirlenmiştir. Aynı çalışmada yapılmış hisse senedi kanalı varyans ayrıştırmaları çalışmasına bakıldığında ise faiz oranının IMKB endeksi içerisindeki payı ortalama olarak \%5,33 gibi çok düşük seviyedeki bir değer olarak belirlenmiştir. Benzer şekilde reel üretim varyans araştırma sonuçları incelendiğinde ise IMKB endeksinin reel üretimdeki değişiklikleri açıklama gücü ortalama olarak \%0,65 seviyesinde gerçekleşmiştir. Tüm bu sonuçlar doğrultusunda Türkiye'de hisse senedi fiyatları kanalının etkin bir şekilde çalışmadığı anlaşılmıştır.

Sezer (2003), yaptığı ampirik çalışma sonucunda döviz kuruna ve faiz oranına verilen şoklara sanayi üretim endeksinin güçlü tepki verdiği ancak Türkiye'de hisse senedi piyasasının yeterli düzeyde gelişmişliğe sahip olmaması nedeniyle Türkiye'de hisse senedi fiyatları kanalının çalışmadığı tespit edilmiştir. 


\section{Durmuş Çağrı YILDIRIM | Mustafa Uğur MiRASEDOĞLU}

Kasapoğlu (2007),iMKB endeksindeki şoka sistemdeki diğer değişkenlerin gösterdikleri tepkileri ölçen etki tepki fonksiyonu çalışmasında, IMKB değişkenindeki bir standart sapma değerindeki şoka sistemde bulunan diğer değişkenler içerisinde sadece para arzı değişkeni anlamlı bir tepki vermiştir. Enflasyon değişkeninin ve sanayi üretimi değişkeninin anlamlı tepki vermemiş olması ise, hisse senedi fiyatları kanalının Türkiye'de çalışmadığının göstergesidir. Hisse senedi fiyatları kanalının Türkiye'de çalışmamasının, hisse senedi piyasasının Türkiye'de yeterli derinliğe sahip olmaması sebebiyle olduğu düşünülmektedir.

\section{Türkiye'de Hanehalkının Hisse Senedi Yatırımları}

BDDK'nın Aralık 2010 ve Aralık 2012 tarihli Finansal Piyasalar Raporları ile TCMB'nin 2014 tarihli Finansal İstikrar Raporu incelendiğinde 2003 - 2014 yılları arasında hanehalkı finansal varlıkları ve yükümlülükleri farklı kalemler altında toplulaştırıımış bir şekilde görülebilmektedir. Bu raporlardaki veriler ışığında hanehalkı hisse senedi varlıklarının toplam varlıkları içerisindeki payı 2003 - 2014 yılları arasındaki dönem için incelendiğinde çıkan sonuçlar Tablo-1'de görülmektedir.

Tablo 1. Hanehalkı Hisse Senedi Yatırımlarının Toplam Varılıkları İçerisindeki Payı (\%)

\begin{tabular}{lllllllllllll}
\hline $\begin{array}{l}\text { Mil- } \\
\text { yar } \\
T L\end{array}$ & 2003 & 2004 & 2005 & 2006 & 2007 & 2008 & 2009 & 2010 & 2011 & 2012 & 2013 & 2014 \\
\hline $\begin{array}{l}\text { Hisse } \\
\text { Se- } \\
\text { nedi }\end{array}$ & 9,2 & 12,4 & 15,8 & 15,7 & 17,5 & 10,8 & 24,5 & 32,6 & 30,0 & 37,7 & 38,5 & 37,1 \\
$\begin{array}{l}\text { Top. } \\
\text { Var- } \\
\text { lıklar }\end{array}$ & 156,0 & 190,7 & 216,3 & 256,0 & 281,8 & 353,8 & 402,0 & 450,3 & 514,3 & 572,0 & 679,3 & 730,1 \\
$\begin{array}{l}\text { Oran } \\
\text { (\%) }\end{array}$ & 5,89 & 6,50 & 7,30 & 6,13 & 6,21 & 3,05 & 6,09 & 7,23 & 5,83 & 6,59 & 5,66 & 5,08 \\
\hline
\end{tabular}

Kaynak: BDDK, Aralık 2010; BDDK, Aralık 2012; TCMB, 2014

BDDK tarafından yapılmış olan Finansal Piyasalar Raporu (Aralık, 2010; Aralık, 2012) ve TCMB tarafından yapılmış olan Finansal İstikrar Raporu (Mayıs, 2014) detaylı olarak incelendiğinde Türkiye'de hanehalkının hisse senedi varlıklarının toplam varlıkları içerisinde çok düşük bir paya sahip olduğu görülmektedir. Bu veriler ışığında Türkiye'de hisse senedi piyasasının hanehalkı tarafından yaygın olarak tercih edilmemesi nedeniyle yeterli derinliğe ulaşamadığı görülmektedir. Yerli literatürde de hisse senedi fiyatları kanalının Türkiye'de etkin çalışan bir kanal olmadığı sonucuna ulaşımasının da nedeninin Türkiye'de hisse senedi piyasasının yeterli derinliğe ulaşamaması olduğunu düşünmekteyiz. Çalışmamızın sonuç bölümünde buna yeniden değineceğiz. 


\section{Ekonometrik Analiz}

Ekonometrik Analiz başlı̆ında öncelikle metodoloji ve veri seti tanıtılacak sonra ampirik analiz ve bulgulara yer verilecektir.

\subsection{Metodoloji ve Veri Seti}

Bu çalışmada hisse senedi fiyatlarındaki değişimin bir yandan hanehalkı refahı diğer yandan yatırım harcamaları üzerinden hasıla seviyesi üzerinde bir etkisinin olup olmadığı incelenecektir. Parasal Aktarım Mekanizmasının Hisse Senedi Fiyatları Kanalı üzerine yapılan çalışmalarda vurgulandığı üzere para politikası uygulamaları sonucu değişen hisse senedi fiyatları, bu hisseleri portföyünde bulunduran hanehalkının servetinin artışına neden olarak tüketim harcamalarının artmasına ve nihayetinde hasıla artışına yol açmaktadır.

Diğer yandan Tobin q teorisine göre para politikası uygulamaları sonucunda artan hisse senedi fiyatları, sermaye yenileme maliyetinin görece ucuzlamasına neden olarak şirketlerin yatırımlarını artmasını ve dolayısıyla hasılanın artmasını sağlayacaktır.

Parasal aktarım mekanizması literatürü incelendiğinde VAR analizi para politikası aktarım mekanizması kanallarının ekonomi üzerindeki etkilerinin incelenmesinde tercih edilen bir metodoloji olduğu görülmektedir. VAR metodolojisi, politika yapıcıların uyguladıkları politikaların içsel (endojen) tepki ile dışsal (eksojen) etkisini ayırt etmeye imkan vermektedir (Smets ve Wouters, 1999: 490). Diğer bir ifade ile para politikalarının yol açtığı negatif bir şoka karşılık ekonomik değişkenlerin vermiş oldukları tepkiler ve bu tepkilerin istatistiksel olarak anlamlılığı VAR metodolojisi çerçevesinde incelenebilmektedir.

VAR analizi Sims (1972) tarafından ortaya konuş bir tahmin yöntemidir. VAR analizi içerisinde oluşturulan eşanlı denklem sistemlerinde yer alan tüm seriler içsel olarak kabul edilmektedir. Analizde tüm değişkenlerin hem kendi hem de diğer değişkenlerin geçmiş değerleri yer almaktadır. Dolayısıyla içsel olarak kabul edilen serilerin karşılıklı etkileşimleri analiz edilebilmektedir. VAR analizinden elde edilen sonuçların yorumlanması için etki tepki analizi ve varyans ayrıştırma yöntemlerinden yararlanılabilmektedir.

Çalışmamızda para politikası uygulamalarını temsil etmek üzere literatürde yaygın olarak kullanılan bankalararası gecelik faiz oranları kullanılmıştır. Hisse senedi fiyatlarını temsil etmek üzere BiST 100 endeksi kullanılmıştır. Hanehalkı refah seviyesini temsil etmek üzere sabit fiyatlarla hanehalkı tüketim harcamaları serisi ve yatırım harcamalarını temsil etmek üzere sabit fiyatlarla sabit sermaye oluşum oranı serisi kullanılmıştır. Son olarak hasılada ortaya çıkan değişimi temsil etmek üzere sanayi üretim endeksi kullanılmıştır.

İncelenen veriler TCMB EVDS sisteminden elde edilmiştir. Veriler çeyrek dönemliktir. İnceleme dönemi başlangıç yılı örtük enflasyon hedeflemesinin başladığı 2002 yılı olarak seçilmiştir. 2001 yıIında yaşanan krizin ardından güçlü ekonomiye geçiş programı çerçevesinde Merkez Bankası, 2002

yılından itibaren ise "örtük enflasyon hedeflemesi" ile "açık enflasyon hedeflemesi rejimine" yakın- 


\section{Durmuş Çağrı YILDIRIM | Mustafa Uğur MiRASEDOĞLU}

sama stratejisi benimsemiştir. 2001 yılında yaşanan kriz ardından enflasyon hedeflemesine geçilmesi para politikasında önemli bir kırılma ortaya çıkarmıştır. Para politikası ve kriz döneminde politika uygulamalarının etkilerinde ciddi sapmalar ortaya çıkabilmektedir. Dolayısıyla kırııma dönemi sonrası 2002Q1-2014Q2 dönemi analiz dönemi olarak seçilmiştir. Tablo 2'de analizde kullanılacak verilerin kısaltmaları görülmektedir.

Tablo2. Analizde Kullanılan Seriler

\begin{tabular}{ll}
\hline \hline GFO & Bankalararası Gecelik Faiz Oranı \\
BIST & BisT 100 Endeksi \\
SSO & Sabit Sermaye Oluşum Oranı \\
TUK & Yerli ve Yabancıların Yurtiçi Tüketimleri \\
SUE & Sanayi Üretim Endeksi \\
\hline
\end{tabular}

GFO serisinin sabit ve trend etkilerine sahip olduğu görülmüş ve seri bu etkilerden arındırılmıştır. İstanbul Menkul Kıymetler Borsası (IMKB), 5 Nisan 2013 tarihinde Borsa İstanbul (BIST) olarak değiştirilmiştir. Bu tarihten önce IMKB 100 Endeksi verileri analize dahil edilmiştir. BIST serisinin logaritması alınarak sabit ve trend etkilerinden arındırıımıştır. SSO, TUK ve SUE serilerinin mevsimsellik etkilerine sahip olduğu görülmüştür. TUK serisinin logaritması alınarak her bir seri Tramo/Seats yöntemi ile mevsimsellikten arındırımıştır. Bu seriler ayrıca sabit ve trend etkilerinden de arındırıımıştır.

\subsection{Ampirik Analiz}

Hisse senedi fiyatları kanalının etkinliği VAR metodolojisi ile araştırılacaktır. VAR metodolojisi içerisinde etki tepki analizi ve varyans ayrıştırma analizi elde edilen sonuçların yorumlanması için kullanılan araçlardır. Ancak durağan olmayan serilerle yapılan analizler sahte regresyon sorununa yol açtı̆̆ı için öncelikle serilerin durağanlı̆̆ı araştırılacak sonrasında ise optimum gecikme uzunluğunun tespit edilmesi için LR testine başvurulacaktır. Nihayetinde VAR analizinde elde edilecek etki tepki analizi ile hisse senedi fiyatları kanalının etkinliği araştırılabilecektir.

Hisse senedi fiyatları kanalının içerisinde yer alan refah etkisi ve yatırım etkilerine ilişkin yapılacak VAR analizi sıralamaları, Tablo 3 ve Tablo 4'de görülmektedir.

Tablo 3. VAR Analizi Sıralaması (Refah Etkisi)

\begin{tabular}{|c|c|c|c|c|c|c|}
\hline $\begin{array}{l}\text { Para Politikasında } \\
\text { Ortaya Çıkan Deği- } \\
\text { şiklik }\end{array}$ & $\rightarrow$ & $\begin{array}{c}\text { Hisse Senedi Fi- } \\
\text { yatlarındaki De- } \\
\text { ğişim }\end{array}$ & $\rightarrow$ & $\begin{array}{l}\text { Hanehalkı Refah } \\
\text { Seviyesindeki De- } \\
\text { ğişim }\end{array}$ & $\rightarrow$ & $\begin{array}{l}\text { Hasılada Or- } \\
\text { taya Çıkan De- } \\
\text { ğişim }\end{array}$ \\
\hline GFO & & BIST & & TUK & & SUE \\
\hline
\end{tabular}


Eskişehir Osmangazi Üniversitesi Sosyal Bilimler Dergisi

Tablo 4. VAR Analizi Sıralaması (Yatırım Etkisi)

\begin{tabular}{|c|c|c|c|c|c|c|}
\hline $\begin{array}{c}\text { Para Politikasında } \\
\text { Ortaya Çıkan Deği- } \\
\text { şiklik }\end{array}$ & $\rightarrow$ & $\begin{array}{l}\text { Hisse Senedi Fi- } \\
\text { yatlarındaki De- } \\
\text { ğişim }\end{array}$ & $\rightarrow$ & $\begin{array}{c}\text { Yatırım stokla- } \\
\text { rında Ortaya Çıkan } \\
\text { Değişim }\end{array}$ & $\rightarrow$ & $\begin{array}{l}\text { Hasılada Or- } \\
\text { taya Çıkan } \\
\text { Değişim }\end{array}$ \\
\hline GFO & & BIST & & SSO & & SUE \\
\hline
\end{tabular}

Tablo 3 ve Tablo 4'de VAR analizinde kullanılacak sıralamalar yer almaktadır. VAR analizinden önce serilerin durağanlık durumları araştırılmıştır. Serilerin birim kök durumuna ilişkin ADF test sonuçları Tablo 5'de görülmektedir.

Tablo 5. ADF Test Sonuçları

\begin{tabular}{cccc}
\hline \hline Değişkenler & ADF Test Istatistiği & Kritik Değer - \% 1 & Kritik Değer - \% 5 \\
\hline GFO & -1.398 & -2.614 & -1.947 \\
BIST & -2.641 & -2.614 & -1.947 \\
TUK & -2.395 & -2.614 & -1.947 \\
SUE & -2.607 & -2.614 & -1.947 \\
SSO & -2.499 & -2.614 & -1.947 \\
& Farkı Alınan Serinin ADF Test Sonucu & \\
DGFO & -4.568 & -2.614 & -1.947 \\
\hline
\end{tabular}

ADF Test sonuçları incelendiğinde GFO serisinin seviyede durağan olmadığı ancak diğer serilerin durağan oldukları görülmektedir. GFO serisinin birinci farkı alındığında serinin durağanlığının sağlandığı görülmektedir. Serilerin durağanlık durumlarının araştırılmasının ardından VAR analizi için optimum gecikme seviyesi LR testi yardımı ile belirlenecektir. LR test sonuçları Tablo 6 'da görülmektedir.

Tablo 6. LR Test Sonuçları

\begin{tabular}{cccccc}
\hline \hline \multicolumn{5}{c}{ Refah Etkisi Modeli için LR Test Sonuçları } \\
Lag & LR & FPE & AIC & SC & HQ \\
0 & NA & $4.45 \mathrm{e}+11$ & 38.17212 & 38.33271 & 38.23198 \\
1 & 137.6086 & $2.91 e+10^{*}$ & $35.44301^{*}$ & $36.24597^{*}$ & $35.74235^{*}$ \\
2 & 17.65961 & $3.70 \mathrm{e}+10$ & 35.66358 & 37.10891 & 36.20238 \\
3 & $27.28766^{*}$ & $3.36 \mathrm{e}+10$ & 35.52195 & 37.60965 & 36.30022 \\
4 & 16.38207 & $4.17 \mathrm{e}+10$ & 35.64799 & 38.37805 & 36.66573 \\
& & Yatırım Etkisi Modeli için LR Test Sonuçları & \\
Lag & LR & FPE & AlC & SC & HQ \\
0 & NA & 0.017155 & 7.286030 & 7.446622 & 7.345897 \\
1 & 171.3137 & 0.000484 & 3.714298 & $4.517259^{*}$ & $4.013634^{*}$ \\
2 & $31.53579 *$ & $0.000418^{*}$ & $3.549415^{*}$ & 4.994745 & 4.088219 \\
3 & 11.65511 & 0.000619 & 3.896304 & 5.984003 & 4.674577 \\
4 & 21.49546 & 0.000640 & 3.839720 & 6.569788 & 4.857462 \\
\hline
\end{tabular}




\footnotetext{
* Indicates lag order selected by the criterion

LR: Sequential modified LR test statistic (each test at $5 \%$ level)

FPE: Final prediction error

AIC: Akaike information criterion

SC: Schwarz information criterion

HQ: Hannan-Quinn information criterion
}

Tablo 6'daki sonuçlar incelendiğinde refah etkisi modeli için uygun gecikmenin 1 olduğu görülmektedir. Yatırım etkisi modeli için de Schwarz bilgi kriterine dayanarak uygun gecikme 1 olarak seçilmiştir. Uygun gecikmenin belirlenmesinin ardından hisse senedi fiyatları kanalının etkinliğinin araştırılması için etki-tepki analizine başvurulacaktır.

\subsection{Etki-Tepki Analizi}

Hisse Senedi Fiyatları Kanalı Refah Etkisi Grafiği'nde ve Hisse Senedi Fiyatları Kanalı Yatırım Etkisi Grafiği'nde görüldüğü üzere faiz oranlarına verilen bir standart sapmalık şok karşısında hisse senedi fiyatları tepki vermemektedir. Diğer bir ifade ile daraltıcı bir para politikası uygulaması sonucunda yükselen faiz oranları hisse senedi fiyatlarını etkilememektedir. Yükselen faiz oranları karşısında tüketim ve yatırım azalmakta ve sonuçta sanayi üretimi daralmaktadır. Ancak bu etki hisse senedi fiyatları üzerinden oluşmamaktadır. Sonuç olarak Türkiye'de inceleme döneminde hisse senedi fiyatları kanalının çalışmadığı sonucuna ulaşılmaktadır. 
Eskişehir Osmangazi Üniversitesi Sosyal Bilimler Dergisi

\section{Hisse Senedi Fiyatlari Kanali (Refah Etkisi)}
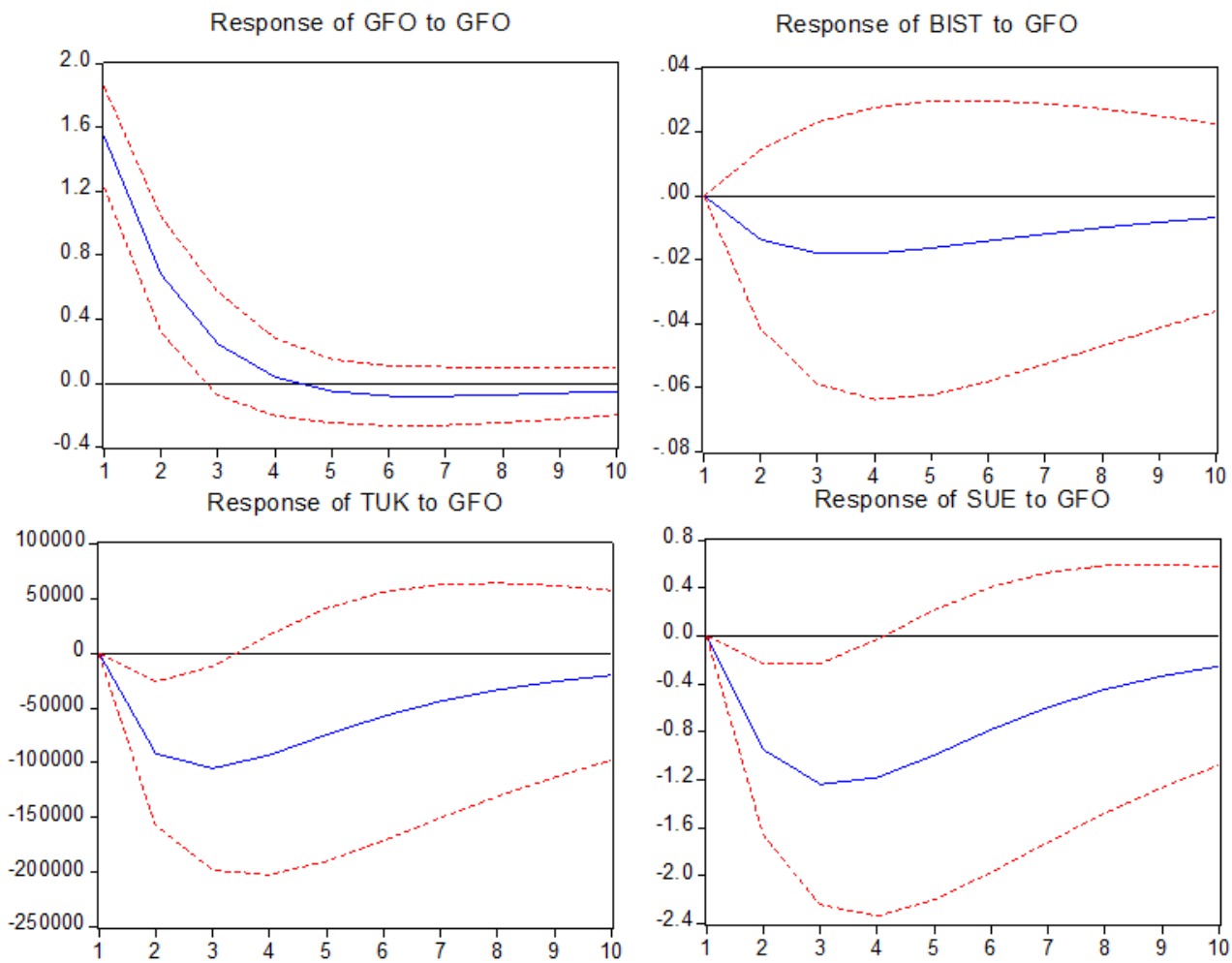


\section{Durmuş Çağrı YILDIRIM | Mustafa Uğur MiRASEDOĞLU}

\section{Hisse Senedi Fiyatlari Kanali (Yatirim Etkisi)}
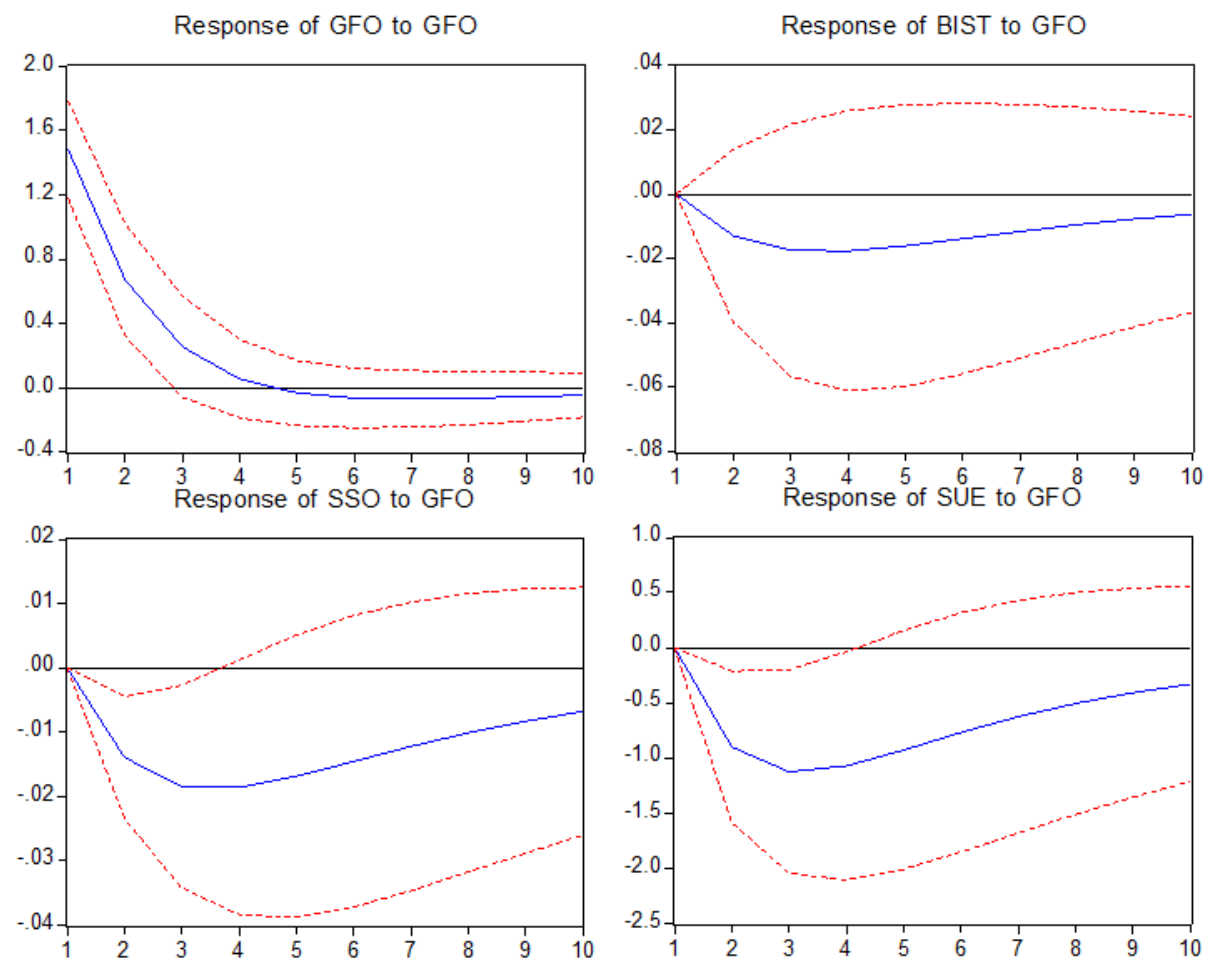

\subsection{Güvenilirlik Testi}

VAR analizinden elde edilen sonuçların güvenilirliğinin araştııımasına ilk olarak otokorelasyon sorunu ile başlanmaktadır. Otokorelasyon sorununun varlığı için LM testi incelenmiş ve bütün olasılık değerlerinin 0,05 'ten büyük olduğu görülmüştür. Dolayısıyla modelde otokorelasyon sorununun mevcut olmadığı sonucuna ulaşımıştır. Güvenilirliğin araştırılmasında ikinci olarak durağanlık testi yapılmıştır. Durağanlık testinde bütün köklerin birim çember içerisinde olduğu görülmüştür. Sonuç olarak her iki model de durağan bir yapıya sahiptir. Grafikler ekte yer almaktadır.

Üçüncü bir analiz ise değişen varyansın araştırılmasına yöneliktir. Analiz sonucunda refah etkisi için elde edilen Ki-kare değerinin 91 ve olasılık değerinin de 0,187 ve yatırım etkisi için Ki-kare değerinin 80 ve olasılık değerinin de 0,454 olduğu sonucuna ulaşılmıştır. Elde edilen bulgulara göre her iki tahmin modelinin de değişen varyansa sahip olmadığını öne süren temel hipotez kabul edilmekte ve modellerde değişen varyans sorununun mevcut olmadığı görülmektedir. Son olarak normallik testi yapılmış ve refah etkisi modeli için Ki-kare değerinin 13.1 olduğu ve Ortak olasılık değeri 
(Jointprobability) değerinin de 0,10 olduğu ve yatırım etkisi modeli için Ki-kare değerinin 6.59 olduğu ve Ortak olasılık değeri (Jointprobability) değerinin de 0,54 olduğu sonucuna ulaşılmıştır. Elde edilen bu bulgulara göre hata terimlerinin normal dağıldığını öne süren temel hipotez kabul edilmektedir. Sonuç olarak her iki modelin de normal dağılımlı olduğu sonucuna ulaşılmıştır.

\section{Sonuç}

Parasal aktarım mekanizmasının hisse senedi fiyatları kanalının etkinliği Türkiye ekonomisi özelinde Merkez Bankasının enflasyon hedeflemesi stratejisine başladığı 2002 ve 2014 yılları arasındaki dönem için çeyreklik verilerle araştırılmışır. Merkez bankası, para politikası uygulamaları ile bir yandan Tobin q teorisi çerçevesinde firmaların sermaye yenileme maliyetlerini nispeten ucuzlatarak ülkenin yatırım stokunun artmasına yol açabilmektedir. Diğer yandan hanehalkının serveti içerisinde hisse senetleri bir yatıım enstrümanı olarak yer almaktadır. Çalışmamız nihayetinde Türkiye ekonomisinde ilgili dönemde hisse senedi fiyatları kanalının hem yatırım hem de refah etkisi üzerinden etkin bir şekilde çalışmadığı sonucuna ulaşılmıştır.

Firmalar özellikle finansal derinliğin mevcut olmadığı gelişmekte olan ülkelerde ihtiyaç duydukları fonların temininde borçlanma ve hisse senedi arzı ile karşı karşıya kalmaktadırlar. Borçlanma, firmalar için hisse senedi arzına nispeten daha küçük bir maliyeti temsil etmektedir. Hisse senedi piyasasında mevcut olan asimetrik bilgi borçlanma maliyetlerini artırırken yeni hisse senedi ihracı ise firmaların bu hisseleri değerlerinden yüksek satacağı düşüncesi ile düşük değerlenmesine neden olmaktadır. Nihayetinde firmaların fon kaynağı olarak hisse senedi piyasasını tercih etmemeleri ya da nispeten daha az yararlanmaları ve fon kaynağı olarak banka kredilerini tercih etmeleri durumunda hisse senedi fiyatlarındaki değişimler ekonominin çıktı seviyesini etkilemeyecektir.

Diğer taraftan hanehalkı için bir yatırım aracı olarak hisse senetlerinin nispeten daha az tercih edilmeleri hisse senedi fiyatlarındaki artışın refah artışı vasıtasıyla tüketim üzerinde bir etkisinin ortaya çıkmamasına neden olacaktır. Hanehalkının hisse senetlerini riskli bulmaları, finansal okur yazarlık oranının düşük olması gibi sebepler bu duruma neden olabilir. Türkiye ekonomisi için yukarıda sayılan nedenler hisse senedi fiyatları kanalının etkin şekilde işleyişini engelleyen faktörler olarak görülebilir.

\section{Kaynaklar}

Ata, H. Ali Ve Ağ Yusuf (2010). "Firma Karakteristiğinin Sermaye Yapısı Üzerindeki Etkisinin Analizi”, İstanbul Üniversitesi İktisat Fakültesi Ekonometri ve İstatistik Dergisi, Sayı 11, S. 45 - 60

Adanur Aklan, Nejla ve Nargeleçekenler, Mehmet (2012). "Hisse Senedi Piyasasında Para Politikasının Rolü: Türkiye Örneği”, Marmara Üniversitesi I.I.I.B. Dergisi, Cilt 33 Sayı 2, S. 103-128

Akerlof, Geroge (1970). “The Market for Lemons': Quality, Uncertanity and the Market Mechanism", Quarterly Journal of Economics 84

BDDK (Aralık 2010). "Finansal Piyasalar Raporu”, Sayı: 20, Tablo 1.2-5: Hane halkı Finansal Varlık ve Yükümlülükler 
BDDK (Aralık 2012). “Finansal Piyasalar Raporu”, Sayı: 28, Ek Tablo 35: Hanehalkı Finansal Varlık ve Yükümlülüklerinin Gelişimi

Bernanke, Ben S. and Blinder Alan S. (1992). "The Federal Funds Rate and the Channels of Monetary Transmission", American Economic Review

Bernanke, Ben S. and Gertler Mark (1995). "Inside the Black Box: The Credit Channel of Monetary Policy Transmission” NBER Working Paper, No: 5146

Bernanke, Ben S. (2003). "Monetary Policy and Stock Market: Some Empirical Results", The Federal Reserve Board, Widener University, Pennsylvania

Bomfim, Antulio N. (2003). "Pre-announcement Effects, News Effects, and Volatility: Monetary Policy and The Stock Market", Journal of Banking and Finance, 27, 133-151

Boughara, Adel (2003). "What Do We Know About Monetary Policy and Transmission Mechanism in Morrocco and Tunisia?", The 10. Annual Conference of the Economic Research Forum

Conover, C. Mitchell, Jensen, Gerald R. and Johnson, Robert R. (1999). “Monetary Environments and International Stock Returns", Journal of Banking and Finance

Erdoğan, Seyfettin ve Yıldırım, Durmuş Çağrı (2008). “Türkiye'de Döviz Kuru Kanalının İşleyişi: Var Modeli ile Bir Analiz”, í. Ü. Siyasal Bilgiler Fakültesi Dergisi, No: 39 S: 96

Erdoğan, Seyfettin ve Yıldırım, Durmuş Çağrı (2008). “Türkiye'de Döviz Kuru Kanalının İşleyişi: Var Modeli ille Bir Analiz", i. Ü. Siyasal Bilgiler Fakültesi Dergisi, No: 39 S: 97

Ertong, Günnur (2005). "Kredi Çöküşü ve Türkiye'de Varlığının Araştırılması”, T.C. Ankara Üniversitesi Sosyal Bilimler Enstitüsü İktisat Anabilim Dalı, Yüksek Lisans Tezi

Groenewold, Nicolas, "Consumption and Stock Prices: Can We Distinguish Signalling From Wealth Effects?", Department of Economics, University of Western Australia

Gülşen, Ahmet Zafer ve Ülkütaş, Özge (2012). "Sermaye Yapısının Belirlenmesinde Finansman Hiyerarşisi Teorisi ve Ödünleşme Teorisi: IMKB Sanayi Endeksinde Yer Alan Firmalar Üzerine Bir Uygulama", ZKÜ Sosyal Bilimler Dergisi, Cilt 8, Sayı 15

Gür, Ekin Toksöz (2003). “Kredi Kanalının Etkin Çalışması ve Türkiye Uygulaması”, Uzmanlık Yeterlilik Tezi, Türkiye Cumhuriyet Merkez Bankası Bankacılık ve Finansal Kuruluşlar Genel Müdürlüğü, Ankara

Ireland, Peter N. (2005). “The Monetary Transmission Mechanism”, Federal Reserve Bank of Boston Working Paper, No:06-1, 1-13

Kamin, Steven, Turner, P. , Van't Dack, J. (1998). “The Transmission Mechanism of Monetary Policy in Emerging Market Economies: An Overview", BIS, Policy Paper, No:3 
Kanalıcı Akay, Hülya ve Nargeleçekenler, Mehmet (2009). “Para Politikası Şokları Hisse Senedi Fiyatlarını Etkiler Mi? Türkiye Örneği”, Marmara Üniversitesi i.I.B.F. Dergisi, Cilt XXVII, Sayı II, S. $129-152$

Kasapoğlu, Özgür (2007). "Parasal Aktarım Mekanizmaları: Türkiye İçin Uygulama”, Uzmanlık Yeterlilik Tezi, Türkiye Cumhuriyet Merkez Bankası Piyasalar Genel Müdürlüğü Ankara

Kearney, Adrienne A. (1996). "The Effect of Changing Monetary Policy Regimes on Stock Prices", Journal of Macroeconomics, Vol:18, No:3, P:429-447

Kosfeld, Reinhold (2002). "Asset Price Channel and Financial Market", Jahrbücherfür Nationalökonomieund Statistik, S. 440-462

Kulhanek, L. (2012). The relationship between stock markets and gross domestic product in the Central and Eastern Europe. Proceedings Of The 7th International Conference On Currency, Banking And International Finance - How Does Central And Eastern Europe Cope Up With The Global Financial Crisis? pp. 135-145.

Lastrapes, W.D. (1998). "International Evidence on Equity Prices, Interest Rates and Money", Journal of International Money and Finance

Mishkin, Frederic S. (1995). "Symposium on the Monetary Transmission Mechanism", The Journal of Economic Perspectives, Vol:9, No:4

Mishkin, Frederic S. (1996). "The Channels of Monetary Transmission: Lessons for Monetary Policy", National Bureau of Economic Research, Working Paper 5464

Mishkin, Frederic S. (1997). "The Economics of Money, Banking, and Financial Markets", Fifth Edition, Addison-Wesley

Modigliani, Franco ve Miller, Merton (1958). "The Cost of Capital, Corporation Finance and The Theory of Investment", The American Economic Review, 48

Modigliani, Franco ve Miller, Merton (1963). "Corporate Income Taxes and the Cost of Capital: A Correction", The American Economic Review, 53

Neri, Stefano (2002). "Monetary Policy and Stock Prices: Theory and Evidence”, Bank of Italy

Okuyan, H. Aydın, Taş̧̧ı, H. Mehmet (2009). “iMKB’de İşlem Gören Üretim İşletmelerinde Sermaye Yapısının Belirleyicileri", Anadolu International Conference in Economics

Ökte, Kutluhan S. (2001). “Finansal Piyasalarda Asimetrik Enformasyon Problemi: Temel Kavramlar, Literatür ve Çözüm Önerileri”, Uludağ iïBF Dergisi, Cilt:19, Sayı:12

Önder, Timur (2005). “Para Politikası: Araçları, Amaçları ve Türkiye Uygulaması”, Uzmanlık Yeterlilik Tezi, Türkiye Cumhuriyet Merkez Bankası Piyasalar Genel Müdürlüğü 


\section{Durmuş Çağrı YILDIRIM | Mustafa Uğur MIRASEDOĞLU}

Örnek, İbrahim (2009). "Türkiye'de Parasal Aktarım Mekanizması Kanallarının İşleyişi”, Maliye Dergisi, Sayı 156

Rapach, D.E. (2001). “Macro Shocks and Real Stock Prices”, Journal of Economic sand Business, 53

Rigobon, R. and Sack, B. (2004). "The Impact of Monetary Policy on Asset Prices" Journal of Monetary Economics, 51

Sayman, Yahya (2012). "Sahiplik Yapısının Firma Performansı ve Sermaye Yapısı Üzerine Etkileri: iMKB'de İşlem Gören Üretim Firmalarında Bir Uygulama”, T.C. Ankara Üniversitesi Sosyal Bilimler Enstitüsü, İşletme Anabilim Dalı

Sezer, B. (2003). “Parasal Aktarım Mekanizması ve Türkiye'de İşleyişi”, Yüksek Lisans Tezi, Ankara Üniversitesi Sosyal Bilimler Enstitüsü

Smets, Frank ve Wouters, R. (1999). "The Exchange Rate and the Monetary Transmission Mechanism in Germany", De Economist, 147, (4), 489- 521.

Şahin, Baki Cem (2011). “Para Politikası Kararlarının Hisse Senedi Piyasası Üzerine Etkisi: Türkiye Uygulaması”, Uzmanlık Yeterlilik Tezi, Türkiye Cumhuriyet Merkez Bankası Illetişim ve Dışilişkiler Genel Müdürlüğü, Ankara

TCMB (2013). “Parasal Aktarım Mekanizması”, Türkiye Cumhuriyet Merkez Bankası

TCMB (2014). “Finansal İstikrar Raporu”, Türkiye Cumhuriyet Merkez Bankası, Mayıs-2014 
EK-1

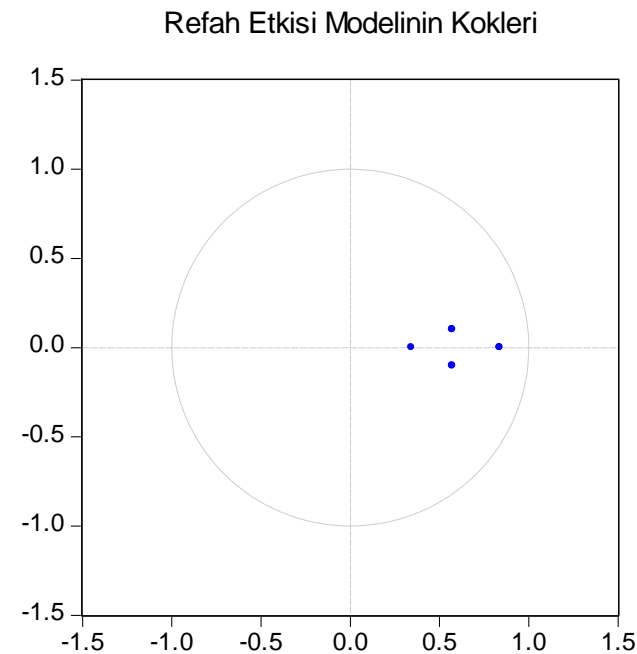

Yatirim Etkisi Modelinin Kokleri

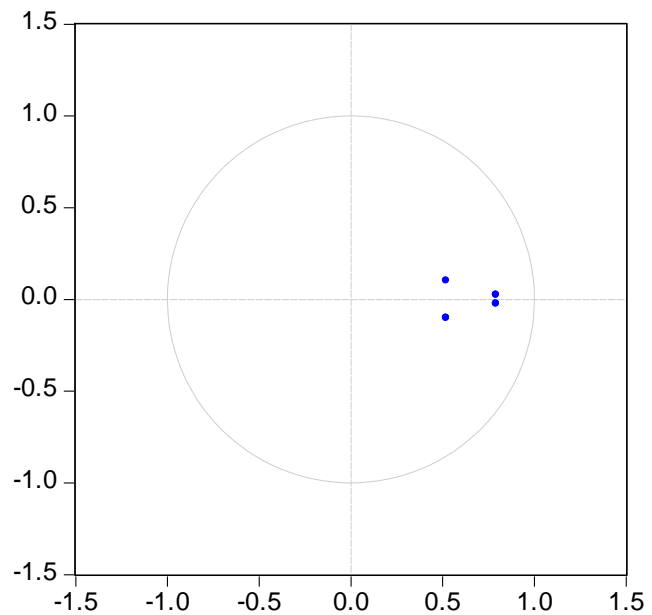


